\title{
Global potential for material substitution in building construction: the case of cross laminated timber
}

\author{
Bernardino D’Amico ${ }^{\mathrm{a}, \mathrm{b}, *}$, Francesco Pomponi ${ }^{\mathrm{a}, \mathrm{b}, \mathrm{c}}$, Jim Hart $^{\mathrm{a}, \mathrm{b}}$ \\ ${ }^{a}$ REBEL (Resource Efficient Built Environment Lab) \\ ${ }^{b}$ School of Engineering and the Built Environment, Edinburgh Napier University, UK \\ ${ }^{c}$ University of Cambridge Institute for Sustainability Leadership (CISL), UK
}

\begin{abstract}
The building and construction sector is a large contributor to anthropogenic greenhouse gas emissions and consumes the vastest amount of natural resources. Widely considered a hard-to-decarbonise sector, improvements in buildings and construction are of fundamental importance for national and global targets to combat climate change. At material level, mitigation opportunities exist in terms of efficiency (using less of the same material) and substitution (using a different material). This article investigates the latter, with a global focus on the use of cross laminated timber to replace concrete floors in steel structural systems. This approach, whilst innovative, does not require any technological development nor upskilling of current professional practice, thus making it an immediately viable solution to accelerate decarbonisation. We combine Material Flow Analysis with Life Cycle Assessment across both spatial and temporal dimensions, accounting for different levels of uptake of the proposed hybrid construction in the next 30 years. Results show that greenhouse gas emissions saving potentials range between 20-80 $\mathrm{Mt} \mathrm{CO}_{2} \mathrm{e}$ (95\% confidence interval) with an average around $50 \mathrm{Mt} \mathrm{CO}_{2} \mathrm{e}$ in the case of full uptake of the hybrid construction system by 2050. Our analysis does not account for carbon sequestration potential in timber, which would make the savings much greater. Still, the overall savings represent a $1.5 \%$ reduction of the annual greenhouse gas emissions generally attributed to construction, thus making it a non-trivial contribution to progress towards global targets of net-zero carbon buildings.
\end{abstract}

Keywords: buildings, frame, structures, design, carbon, mass

\footnotetext{
${ }^{*}$ Corresponding author

Email addresses: b.damico@napier.ac.uk (Bernardino D'Amico), f.pomponi@napier.ac.uk (Francesco Pomponi), j.hart@napier.ac.uk (Jim Hart)
} 


\section{Background}

By 2060 we will have added 230 billion $\mathrm{m}^{2}$ of new construction to our global building stock according to the UK Committee on Climate Change (2018b), which is the equivalent of building Paris every week or Japan every year. As a result of constructing and using these buildings, an additional $415 \mathrm{Gt} \mathrm{CO}_{2}$ are estimated to be released in the atmosphere in the next 40 year (Abergel et al., 2017) which equates to $55 \%$ of the remaining carbon budget (IPCC, 2018) if we are to have a 50\% chance of limiting global warming to $1.5^{\circ} \mathrm{C}$.

Worldwide energy demand for heating and cooling, hot water supply, ventilation, air conditioning and lighting all represent a major cause of anthropogenic greenhouse gases (GHG). Energy-related $\mathrm{CO}_{2}$ emissions from buildings operation were estimated by the International Energy Agency (2019) to be as much as $28 \%$ of the total anthropogenic emissions in 2018. The importance and urgency of improving energy efficiency in buildings has been widely recognised in the last few decades. Policies and building regulations mandating, facilitating or simply encouraging operational energy-efficiency have resulted in the building sector improving its energy intensity (in terms of energy use per $\mathrm{m}^{2}$ ) at an annual average rate of around 1.5\% worldwide (International Energy Agency, 2017). Yet, both global fossil $\mathrm{CO}_{2}$ emissions and GHG concentrations continue to grow annually as evidenced by the World Meteorological Organization and United Nations Environment Programme (2019).

As buildings become increasingly more efficient to operate, embodied energy and carbon becomes the dominant component to focus on. This is reflected in the global attention it is currently receiving, for instance through the latest report from the World Green Building Council (2019) which calls for all new buildings to achieve embodied carbon neutrality by 2050 .

The term embodied accounts for all the energy that is not directly used by the building's occupants but nonetheless it is required to construct the building in the first place, including raw materials extraction, processing and transportation as well as end-of-life activities such as demolition and disposal. The construction of buildings, 
including upstream supply chains, is estimated to account for nearly $6 \%$ of global final energy use and responsible for $11 \%$ of global $\mathrm{CO}_{2}$ emissions (Abergel et al., 2017). Most of this energy and related emissions are attributable to materials production and processing. For instance, manufacture of cement (the binder used in concrete) is alone responsible for 4-7\% of global $\mathrm{CO}_{2}$ emissions (Shanks et al., 2019) whereas global annual demand for iron and steel is estimated to be around 5\% of global emissions (Davis et al., 2018). According to Cullen et al. (2012) more than half of worldwide steel production is destined to the construction sector.

Forecast studies on global population suggest that the current urbanisation trend —of people relocating from rural areas to cities - will continue to grow in the near future (UN, 2018). As a consequence, dense urban forms can be expected to take a greater share of the built environment, replacing sparse forms of building settlements with denser ones such as multi-storeys. For these building types, the vast majority of the overall mass is concentrated in the building structure (Allwood et al., 2012), which is also where the two most widely used and carbon-intensive construction materials (steel and concrete) are found.

\subsection{Steel and concrete}

Steel and concrete are by far the two dominating materials in terms of worldwide energy requirement and their increasing demand has never stopped since the industrial revolution. Forecasts indicate the same trend will continue in the near future (International Energy Agency, 2009b) with steel demand expected to grow by 3.3\% per year to 2.4 Gt in the next five years (PWC-Metals, 2015) and production of cement projected to grow by 0.8-1.2\% per year to 3.7-4.4 Gt in 2050 (International Energy Agency, 2009a).

While incremental reductions of GHG emissions per ton of produced steel and cement are plausible in future scenarios contemplating a highly decarbonised energy grid, the remainder of emissions will be difficult to eliminate given that they are a direct result of chemical reactions involved in the industrial processes: about $60 \%$ of $\mathrm{CO}_{2}$ emissions due to production of cement are from calcination of limestone (Dean et al., 2011) Similarly, the use of coking coal as an additive to reduce iron oxide ore in blast 
furnaces generates 1.6 to 3.1 tons of $\mathrm{CO}_{2}$ per ton of produced steel (International Energy Agency, 2000). Davis et al. (2018) point out to carbon capture and storage or utilisation technologies as the only feasible way to fully eliminate emissions from the steel and cement manufacturing industries. Although promising, Haszeldine (2009) notes that such technologies are currently and mostly at a developmental stage, meaning that by the time they will be ready to be deployed at scale and commercialised the atmospheric stock of greenhouse gases will have likely surpassed what are predicted to be safe levels as currently reported in scientific literature (Allen et al., 2009; IPCC, 2018).

Shifting the technology focus from the manufacturing of structural materials to the building design and construction sectors, a series of strategies for effective and immediate carbon mitigation have been highlighted. One of these is termed material efficiency (Allwood et al., 2011; Allwood, 2018), that is, using less of the same material while providing the same service. Moynihan and Allwood (2014) for instance have empirically demonstrated the widespread practice in current designs to use over-dimensioned structural steel members, thus uncovering the exsisting potential for structural mass reduction. Liew et al. (2017) and Hawkins et al. (2017) have focused on construction innovation to achieve material efficiency by exploring shape-resistant structural systems, or pointing out to optimisation methods as an effective tool to achieve material efficiency in practice (Moynihan and Allwood, 2014; D’Amico and Pomponi, 2018; Lee et al., 2018) as well as maximising the potential for deconstruction and reuse of structural components (Bukauskas et al., 2018; Brütting et al., 2019). Material efficiency can also be achieved through inherently better building forms, that reduce the required materials whilst offering the same function (D'Amico and Pomponi, 2019).

A second technological strategy, contemplated in this paper, is to look at the potential for material substitution, that is, replacing carbon-intensive materials, such as steel and concrete, with low-carbon alternatives while providing the same service. 


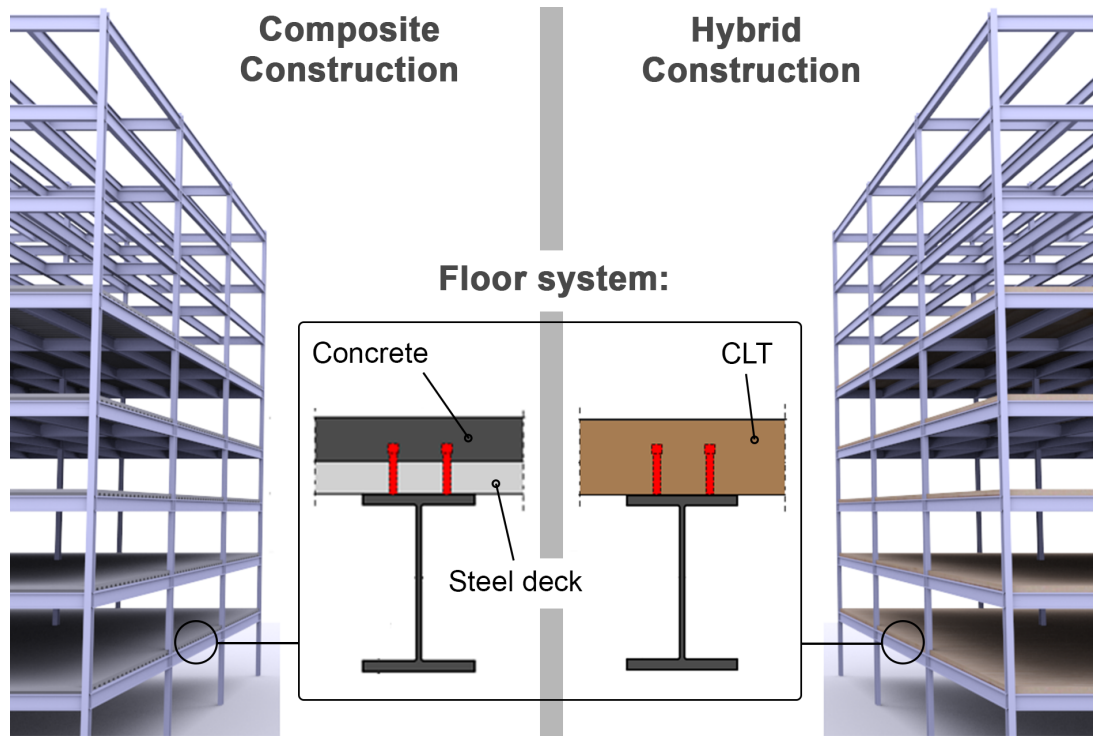

Figure 1: Composite construction is the dominating structural floor system for multi-storey steel framed buildings (SteelConstruction.info, 2018). It comprises of a composite floor slab (with a corrugated steel deck and a concrete topping) which is connected to the supporting steel beams via shear studs (coloured in red) in order to achieve composite action between the slab and beam. In the hybrid construction system the heavy steel-concrete slabs are substituted with cross laminated timber (CLT) panels (Hassanieh et al., 2016)

\section{Material substitution}

\subsection{The case for hybrid steel-timber buildings}

Unlike more traditional forms of timber construction employing the use of sawn wood (e.g. Ballon or Platform framing), glue lamination technology allows the making of structural members made out of timber having arbitrarily large sizes. This has enabled engineered timber products such as glue laminated timber (Glulam) and cross laminated timber (CLT) to become competitors of steel and reinforced concrete in the construction market of medium- to high-rise multi-storey buildings (Kuzmanovska et al., 2018). Currently, the number of tall multi-storey buildings with a Glulam-CLT frame structure (also termed in literature as mass timber buildings (Harte, 2017)) remains negligible compared to those with a steel and reinforced concrete frame. Yet, as Espinoza et al. (2016) point out, the trend in glue- and cross laminated timber production is growing exponentially. Such trend can be expected to continue in the future given the number of pressing calls for a wider uptake of timber in construction coming from 
researchers (Churkina et al., 2020; Foster and Reynolds, 2018; Ramage et al., 2017a) and practitioners (SOM, 2013; Arup Foresight Research and Innovation, 2019). For instance, the UK Committee on Climate Change (2018a) has indicated that greatly increasing uptake of wood products in construction is the most effective options against climate change in using harvested biomass for non-energy generation.

Existing research aimed at comparatively assessing from a whole-life perspective the carbon (Hart and Pomponi, 2020; Salazar and Meil, 2009; Liu et al., 2016; Sandanayake et al., 2018; Yue et al., 2019) and energy (Gustavsson et al., 2006; Robertson et al., 2012; Tettey et al., 2019) footprints and/or other environmental impacts (Crawford and Cadorel, 2017; Lu et al., 2017; Pierobon et al., 2019) of mass timber buildings against the steel or reinforced concrete counterpart generally concur in favour of the former. If we exclude those works focusing at a product level boundary system -i.e. Life Cycle Assessments of CLT panels (Chen et al., 2019; Hassan et al., 2019) - the only existing study assessing the environmental (energy) implications of composite steelCLT building structures at whole-building scale is the one by Chiniforush et al. (2018). However, a study that looks at the potential carbon mitigation benefit of adopting such structural system at global scale seems yet to be carried out. This is the main rationale motivating this work.

Instead of focusing our analysis on full-timber building frames as a replacement for steel or concrete ones, we opted for looking at the potential for partial substitution, specifically: replacing composite (steel-concrete) floor slabs in steel frames with CLT slab panels, as shown in Figure 1. Such a composite structural system involving the coupling of CLT floor slabs with steel members is still at a developmental stage, with ongoing active research mainly aimed at characterising the structural performance in terms of strength/serviceability (Hassanieh et al., 2016; Loss et al., 2016, 2018). Nonetheless, some recent building projects do exist in which such a structural system has been used (Holmes Structures, 2017; Waugh Thistleton Architects, 2018; Ross, 2019) thus proving the practical feasibility of this technology. We termed such construction system hybrid for consistency with the existing literature (Tesfamariam et al., 2014; Hassanieh et al., 
2016; Loss et al., 2016). The case for hybrid steel-CLT framed buildings is twofold:

- The floor system is usually where most of the structural mass concentrates (Allwood et al., 2012), hence, it is where greatest potential for material substitution can be exploited.

- The hybrid steel-CLT solution represents a technological transition in which both 'old' and 'new' materials coexist. Limited awareness of the design and construction communities with regard to the emerging timber technologies available, along with perceived (yet unjustified) disadvantages in terms of fire risk, are some of the existing non-technological obstacles for a wider and faster uptake of all-timber structures in multi-storey buildings as Xia et al. (2014) points out. The hybrid solution is therefore one that can be immediately implemented in building projects.

Regulatory barriers also play their role. Design limits for instance — originally put in place by policy makers having in mind traditional timber construction - exist in many countries on the maximum number of storeys a timber building can achieve. These limits would not apply to a hybrid system like the one under investigation given that the primary structure is made out of steel. Further to this, employing partial substitution at a floor subsystem level would greatly reduce the requirement for knowledge upskill (another barrier for innovation) necessary for engineering practices to carry out their structural designs, therefore increasing the likelihood of them considering timber-based structural materials for their clients' projects.

\section{Methods}

In order to estimate the global warming potential (GWP) mitigation potential deriving from gradual substitution of composite floor slabs with CLT, we express the annual flow of GHG emissions at year $t$ as the dot product between the two vectors $\bar{M}$ and $\bar{e}$.

$$
G H G^{t}(u)=\bar{M}^{t}(u) \cdot \bar{e}
$$


Entries in the first vector are estimates of material mass quantities (for both traditional and hybrid structural systems) required to meet global construction demand for steel building frames at a given year $t$. For each material mass entry in $\bar{M}$ the second vector, $\bar{e}$, contains the corresponding carbon coefficients (CC) which represent the amount of greenhouse gases $\left(\mathrm{CO}_{2} \mathrm{e}\right)$ released in the atmosphere per unit mass of material. To enable future scenario modelling accounting for various degrees of material substitution we introduce a factor, $u$, representing the fraction of hybrid construction uptake to be achieved at the end of the reference period 2020-2050 (i.e. for $u=0 \Rightarrow$ no uptake; for $u=1 \Rightarrow 100 \%$ uptake by 2050). The vectors of materials and corresponding carbon coefficients are provided as follows:

$$
\bar{M}(u)=\left[\begin{array}{c}
M_{s f}(u) \\
M_{c}(u) \\
M_{s d}(u) \\
M_{C L T}(u)
\end{array}\right] \quad ; \quad \bar{e}=\left[\begin{array}{c}
e_{s f} \\
e_{c} \\
e_{s d} \\
e_{C L T}
\end{array}\right]
$$

with each subscript indicating the structural material (or component) being considered. With reference to Figure 1:

- $s f=$ Bare steel frame (i.e. beams and columns)

- $c=$ Concrete (in composite floor slabs)

- $s d=$ Steel deck (in composite floor slabs)

- $C L T=$ Cross laminated timber (floor slabs)

Global end-use for these materials at a given year $t$ in the future will depend on two main factors: future demand for construction of buildings with a steel frame; and fraction of those buildings that will be constructed using hybrid (steel-CLT) technology. Unlike for material quantities, it can be seen from Equation (1) that carbon coefficients are assumed to be static over time. We estimate such coefficients (along with their uncertainty) based on the current GHG emission intensity of the energy grid (see section 
3.4). According to the International Energy Agency (2018) World Energy Outlook both

(a)

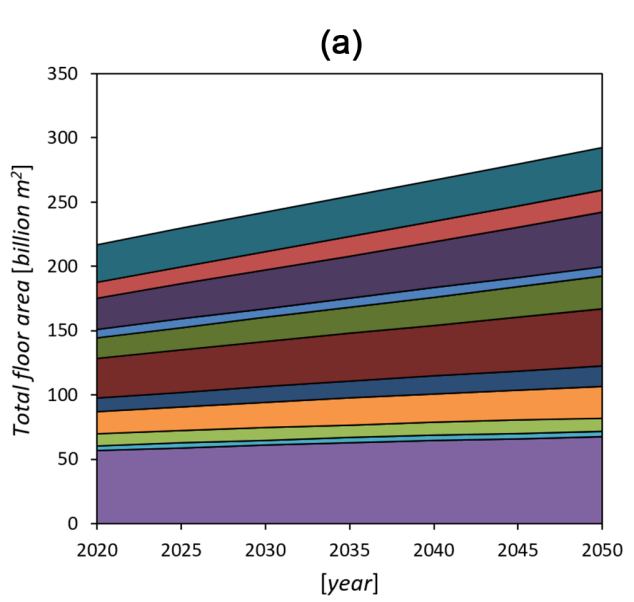

a significant increase in energy demand and carbon emissions as well as a decrease in carbon emissions — whilst supplying the same amount of energy - are equally likely between now and 2040. Even when new policies announced by government are factored in, emissions and energy demand still both increase without peaking before 2040. As the International Energy Agency acknowledges that all scenarios are equally probable it would be almost a random choice picking one that can realistically represent the future. For this reasons we adopt the conservative hypothesis of maintaining current carbon coefficients for materials flat through the 2020-2050 reference period. Whilst this might seem an oversimplification is a conservative standpoint based on collected data.
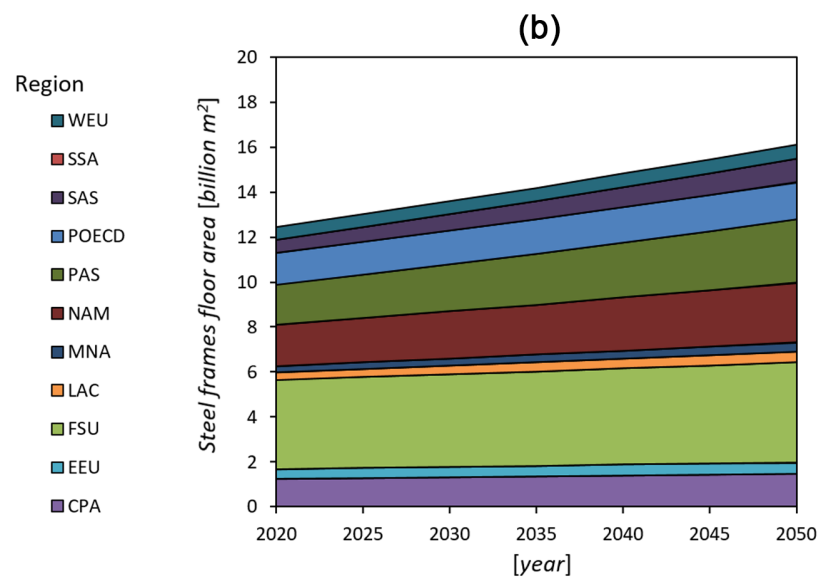

Figure 2: (a): global projections of urban floor area based on the baseline density scenario (S50) from Güneralp et al. (2017). (b): corresponding share of steel building frame floor area. The 11 International Energy Agency regions are: Centrally Planned Asia and China (CPA), Central and Eastern Europe (EEU), newly independent states of the former Soviet Union (FSU), Latin America and the Caribbean (LAC), Middle East and North Africa (MNA), North America (NAM), Other Pacific Asia (PAS), Pacific countries members of the Organization for Economic Cooperation and Development (POECD), South Asia (SAS), Sub-Saharan Africa (SSA), and Western Europe (WEU).

\subsection{Floor area projections}

To model future demand of material use in steel building frames $(\bar{M})$, we first look at global forecasts of urban floor area, $\Lambda_{u r b}^{t}$, for the entire reference period 2020 to 2050. Based on this, we then derive urban floor area projections specifically for buildings with 
a steel frame $\Lambda_{s f}^{t}$, taken as a percentage $(\rho)$ of total urban floor area projections:

$$
\Lambda_{s f}^{t}=\rho \Lambda_{u r b}^{t}
$$

Growth estimates of global urban floor area are taken from Güneralp et al. (2017). which provide cumulated values at five-year intervals up to 2050 for each of the 11 International Energy Agency regions. Their estimates account for three different future urban density scenarios: low (S25), baseline (S50) and high (S75). Of these floor area projections, a certain percentage, $\rho$, will be represented by steel building frames. While it remains extremely uncertain what such percentage might be in the future, a reasonable approach is to look at estimates of the existing building stock, worldwide. For this purpose we adopt PAGER (Jaiswal and Wald, 2008), a global building inventory database which provides population percentages per structural building type at country level, for both urban and rural categories. Projections of total urban floor area (S50 scenario) and corresponding shares of steel building frames are both shown in Figure 2, color-coded for each region. The Figure shows a clear variation among regions with regard to their internal building stock shares of steel frames. Based on this model, steel frame floor area accounts for about $6 \%$ of the total global (urban) building floor area. Methodological information on how the fractions of building frames (as from PAGER) were aggregated from country-level to regions can be found in supplementary material.

\subsection{Material intensities}

Having derived worldwide building floor area projections for steel frames $\left(\Lambda_{s f}^{t}\right)$, the material flows (annual or cumulated) required to construct them can be derived by multiplying the floor area projections with the corresponding material intensities, $m$ (i.e. masses of structural material per unit of floor area). Material intensities were taken as follows (in $\left.\mathrm{kg} / \mathrm{m}^{2}\right)$ :

- $m_{s f, c o m p}=30.8(\mu) ; 6.43(\sigma)$

- $m_{s f, h y b}=27.7(\mu) ; 5.33(\sigma)$ 
- $m_{c}=230.0$

- $m_{s d}=14.3$

- $m_{C L T}=65.0(\min ) ; 75.0(\max )$

Mass distributions of steel beams and columns in composite and hybrid frames $m_{s f, c o m p}$ and $m_{s f, h y b}$ respectively - were modelled explicitly via automated structural design/optimisation techniques (D'Amico and Pomponi, 2018). A parametric structural frame model was implemented and used to generate a population of 20'000 steel frame designs to account for a range of realistic geometric and loading configurations. Histograms of steel intensities $m_{s f, c o m p}$ and $m_{s f, h y b}$ are shown in Figure 3a and 3b respectively. Input parameters and details of the automated design/optimisation algorithm can be found in supplementary material. As shown in Figure 3, substituting heavy steel-concrete composite floor slabs with CLT panels yield to an average steel mass reduction of circa $3.1 \mathrm{~kg} / \mathrm{m}^{2}$. The mass intensity values for the floor slabs $\left(m_{c}=230.0\right.$, $m_{s d}=14.3$ and $m_{C L T}=65.0$ ) are based on manufacturers' data (see supplementary material).

(a)

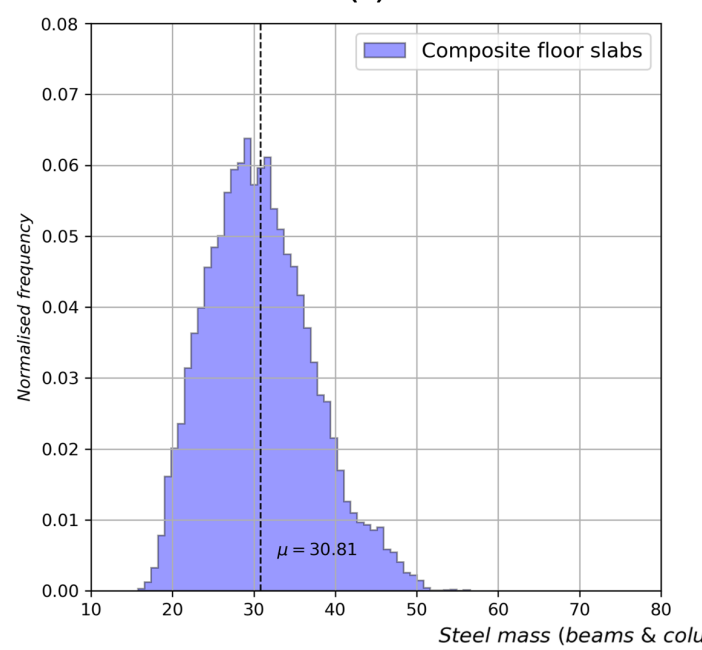

(b)

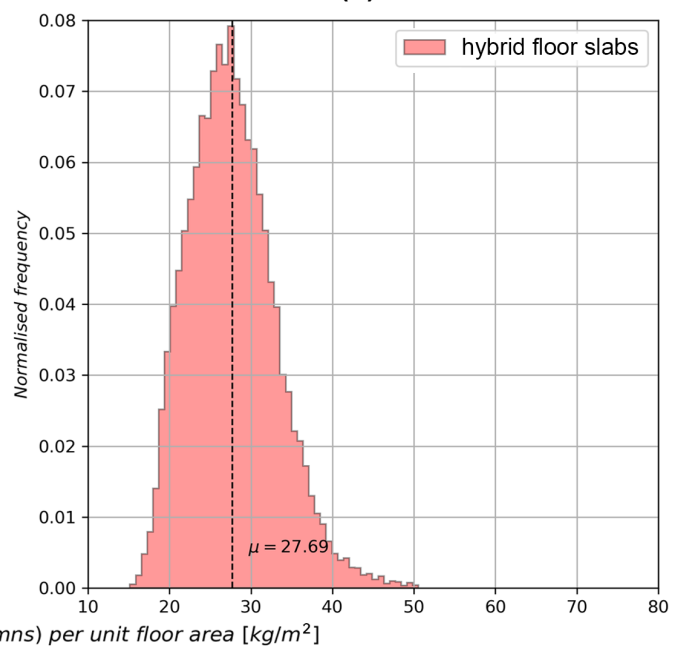

Figure 3: Histograms of mass intensity for the bare steel frame for (a): traditional (composite) construction; (b): hybrid construction. 


\subsection{Global material quantities}

Global material quantities, $\bar{M}$, required to meet future annual demand for construction of steel building frames can be now derived as a function of material intensities $(m)$, floor area projections $\left(\Lambda_{s f}^{t}\right)$ and fraction of hybrid construction uptake by 2050 (u). To match with floor area projection data, the reference period 2020-2050 is divided into $n=6$ five-year intervals. The global yearly demand for steel frame sections (beams and columns) is thus computed as follows for the $i$ th five-year interval:

$$
M_{s f}^{i}(u)=\frac{\Lambda_{s f}^{i}\left[\left(1-u \alpha^{i}\right) m_{s f, c o m p}+u \alpha^{i} m_{s f, h y b}\right]}{5}
$$

where $\alpha^{i}$ is the rate of hybrid construction uptake at the end of the $i$ th (five-year) interval, which is assumed to increase linearly throughout the reference period 20202050:

$$
\alpha_{i}=\frac{i}{n}
$$

Similarly, projected annual flows for concrete and steel deck sheathing (in composite floor slabs) and CLT floor slabs can be derived as follows:

$$
M_{c}^{i}(u)=\frac{\Lambda_{s f}^{i}\left(1-u \alpha^{i}\right) m_{c}}{5}
$$

$$
\begin{aligned}
& M_{s d}^{i}(u)=\frac{\Lambda_{s f}^{i}\left(1-u \alpha^{i}\right) m_{s d}}{5} \\
& M_{C L T}^{i}(u)=\frac{\Lambda_{s f}^{i} u \alpha^{i} m_{C L T}}{5}
\end{aligned}
$$

Plots of Eq. (4) and Eqs. (6) to (8) are shown in Figure 4a in Mt/yr considering different levels of uptake by 2050 for the hybrid system. The extreme scenarios are: no uptake (blue line) and full uptake (red-dashed line). Mean values were set for $m_{s f, c o m p}$ and $m_{s f, h y b}$ in generating these annual material flows. The corresponding cumulated quantities, shown in Figure 4b, were obtained via numerical integration, interpolating 
linearly the data-points of the annual flows.
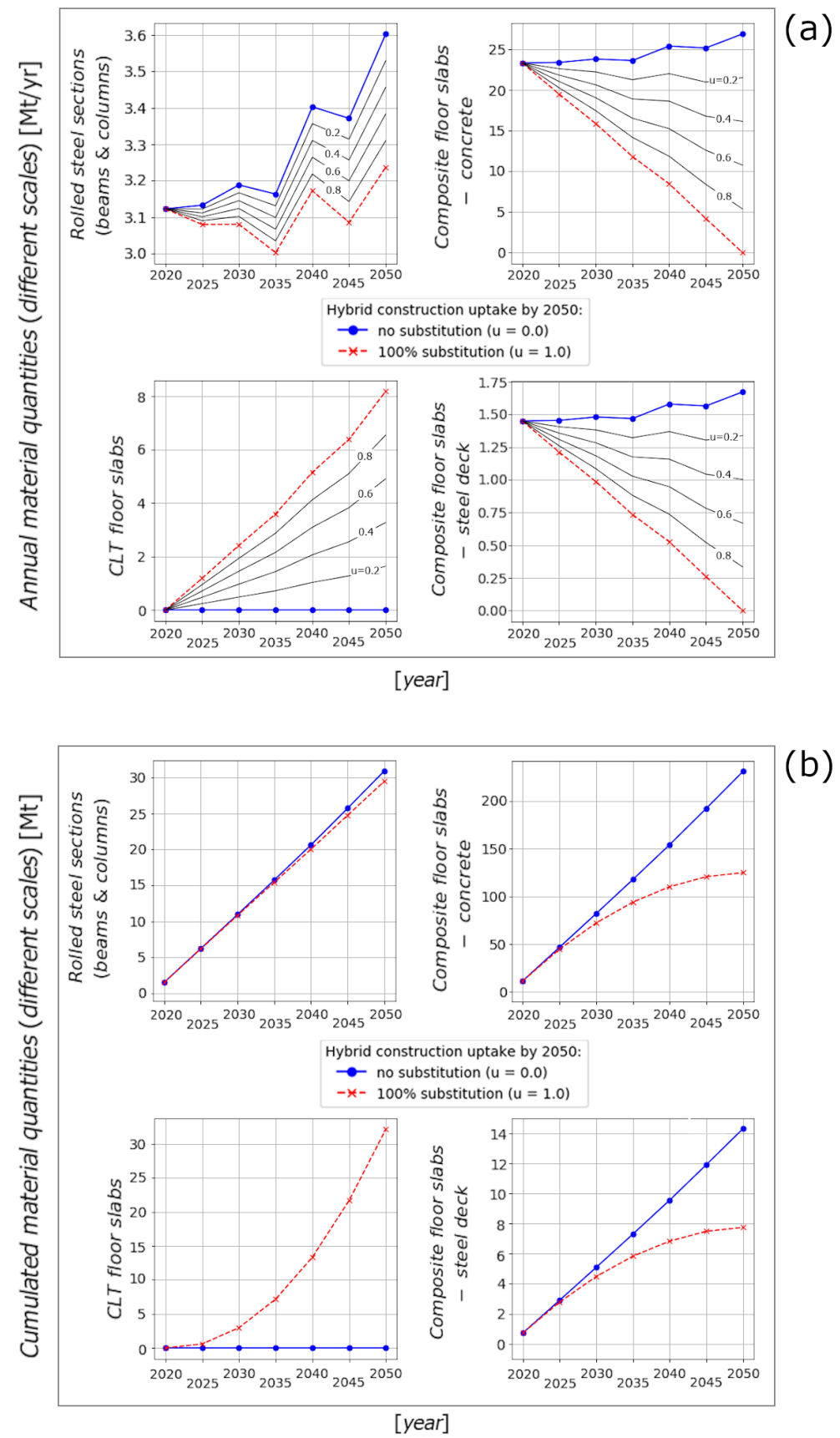

(b)

Figure 4: Global projections of materials demand for steel building frames assuming different values for the uptake factor $u$. The two extreme scenarios are: Business as usual $(u=0.0)$ composite steelconcrete floor slabs remain the most widespread method of construction; Full substitution $(u=1.0)$ hybrid construction with CLT floor slabs becomes the mainstream technology by 2050 . 


\subsection{Carbon coefficients}

Distributions of whole-life carbon coefficients, $e$, are derived for each structural material in terms of mean and standard deviation.

- $e_{s f}=2.24(\mu) ; 0.53(\sigma)$

- $e_{c}=0.45(\mu) ; 0.13(\sigma)$

- $e_{s d}=2.48(\mu) ; 0.53(\sigma)$

- $e_{C L T}=1.08(\mu) ; 0.2(\sigma)$

Lower/upper value ranges (and most likely value, when available) are first estimated for each life cycle stage (including end-of-life) in line with standardised procedure for Life Cycle Assessment of construction works (European Committee for Standardization, 2011). The above distributions of aggregated whole-life CCs are then derived numerically, via Monte Carlo method with whole-life data-point coefficients obtained as sum of the partial coefficients randomly sampled from each life cycle stage distribution (Pomponi et al., 2017). The Monte Carlo method is relatively straightforward to implement as it only requires the input values to be re-assigned at each iteration (by randomly picking from predefined distributions), while the output-generating model is the same at every iteration. A downside of the method is the requirement for a sufficiently large number of iterations in order to achieve consistency of results. The minimum number of required iterations was calibrated by running the algorithm several times, hence making sure the means of the output distributions were within $\pm 1 \%$ of their average. Numerical values defining the partial coefficient input distributions, as well as the underpinning methodology herein adopted to derive them, are both detailed in supplementary material.

It is however worth to mention here that the carbon sequestrated in timber during the tree-growing stage has not been accounted for in characterising the carbon coefficients for CLT. Such biogenic carbon compounds will eventually be released back in the atmosphere as $\mathrm{CO}_{2}$ at a later (however far) time in the future past the building's endof-life. Sequestrated carbon should therefore be treated as source of emissions offsetted 
in time rather than credited as absolute gain. Strategies to offset emissions in the near term are indeed very much needed given the short time-frame available for action (as warned by the IPCC (2018)). While acknowledging the benefit of large-scale engineered wood products uptake in building construction (coupled with forest replantation) as a way to create an artificial global carbon sink (Churkina et al., 2020), characterising its time-limited extent requires further value judgement (e.g. buildings' lifespan, just to name one) which is beyond the scope of our analysis. Further, our approach represents a conservative hypothesis in light of the validity of our findings.

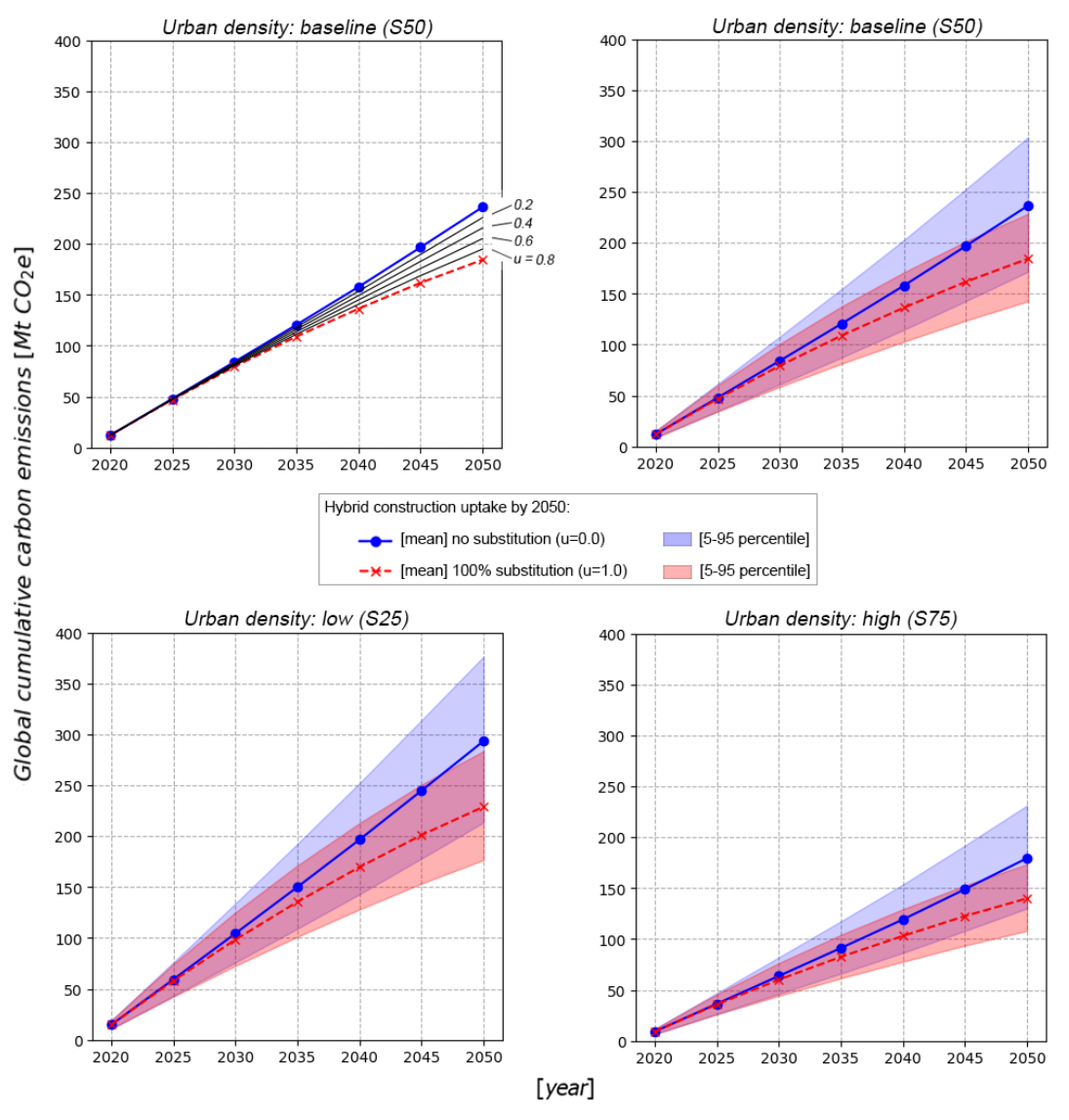

Figure 5: Global cumulated projections of GHG emissions up to 2050 with uncertainty bands, derived based on annual flows as from Eq. (1) for the low, medium and high future urban density scenarios from Güneralp et al. (2017). Mean GHG emission trajectories as a function of hybrid construction uptake ratio at $2050(u)$ are also shown for the medium urban density scenario. 


\section{Results}

Cumulated projections of GHG emissions up to 2050 have been derived based on annual flows as from Eq. (1) and shown in Figure 5 for the low, medium and high future urban density scenarios. Uncertainty bands, due to variability in material and emission intensities ( $m$ and $e$ ) are quantified via Monte Carlo simulation. Assuming current global urban densities will remain stable (S50), global demand for buildings with a steel frame structure will result in additional 171-303 $\mathrm{Mt}$ of $\mathrm{CO}_{2} \mathrm{e}$ released into the atmosphere in the next 30 years if current construction practice will remain unchanged by $2050(u=0)$. This range would be lowered to $142-229 \mathrm{Mt} \mathrm{CO}_{2} \mathrm{e}$ if the most optimistic scenario materialises, that is to say, current technology will be fully replaced by hybrid construction by $2050(u=1)$. In mean-value terms this corresponds to a reduction of about $52 \mathrm{Mt} \mathrm{CO}_{2} \mathrm{e}(-22 \%)$ as shown in Figure 6.

\subsection{Urban density}

Due to the existing relationship between floor area per capita and urban density, total emission levels are inversely proportional to this latter, hence implying that denser urban settlements are to be preferred to sparse ones. Nonetheless, as shown in Figure 5, if future urbanisation trends do fall on a low density pathway (S25), it will make for an even stronger case to adopt hybrid construction given the relative increase of avoided GHG emission compared to the high density scenario (S75).

\subsection{Sensitivity to uncertainties}

As Figure 6 shows, projections of GHG that can be avoided via full material sub-

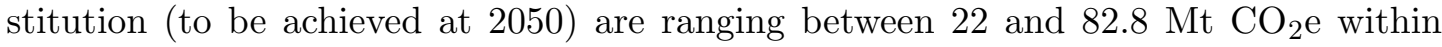
the $5-95 \%$ confidence interval. This uncertainty range is quantified adopting a Monte Carlo analysis in which probability ranges were considered for the pool of model inputs, namely: intensity of whole-life GHG emissions, expressed in terms of carbon coefficients $\left(\mathrm{kgCO}_{2 \mathrm{e}} / \mathrm{kg}\right)$, material intensities per unit of floor area $\left(\mathrm{kg} / \mathrm{m}^{2}\right)$ and total urban floor area projections as function of urban density $\left(\mathrm{m}^{2}\right)$. 


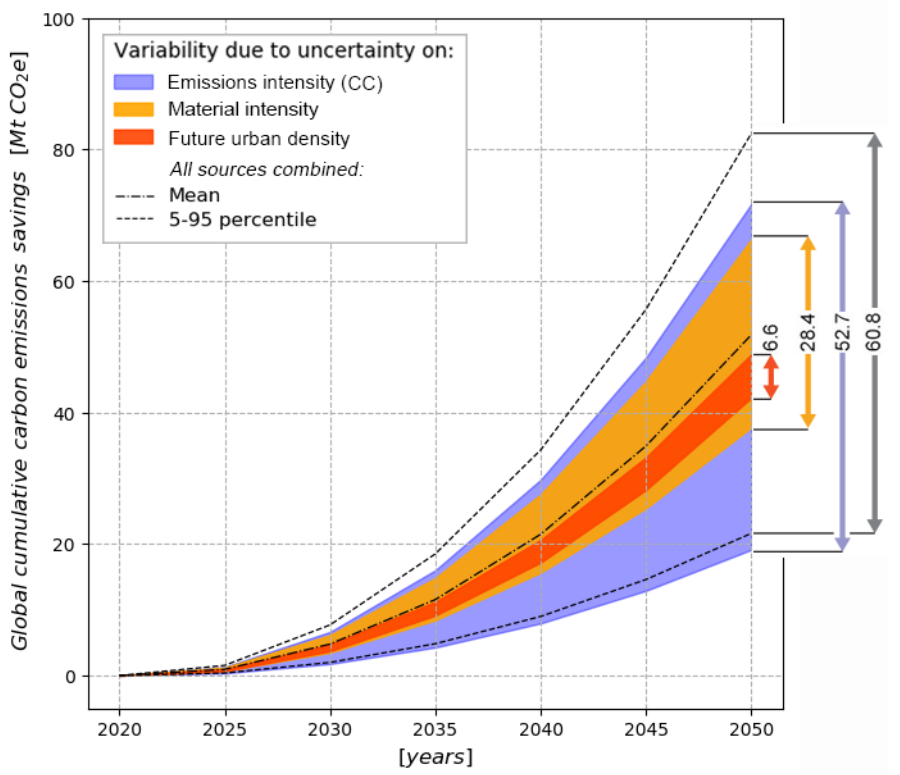

Figure 6: Global cumulated projection of avoided GHG emissions, along with uncertainty, as a result of full material substitution achieved by $2050(u=1)$.

As it can be seen in Figure 6, the influence of individual uncertainty sources on the magnitude of avoided GHG emissions are also individually quantified by running three further Monte Carlo simulations, one for each uncertainty source, in which a single input value (equal to the mean) was set for the remainder of the inputs. Looking separately at the various sources of uncertainty it can be seen from Figure 6 that future urban density

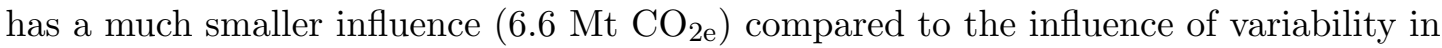
material intensity (28.4 $\mathrm{Mt} \mathrm{CO}_{2 \mathrm{e}}$ ) and uncertainty of carbon emission intensities (52.7 $\left.\mathrm{Mt} \mathrm{CO}_{2 \mathrm{e}}\right)$.

\subsection{Resource availability}

Reaching full material substitution by $2050(u=1)$ is arguably the preferred scenario, and it may be argued on whether such a demand increase for CLT, and its raw material component (sawn timber), can be actually met in practice given the global competitiveness in land use and the limited time-frame of 30 year time. Contrarily to common belief, despite net losses in the tropical regions global tree cover has increased worldwide in the last decades. Song et al. (2018) estimated some +2.24 million $\mathrm{km}^{2}$ in 
the last 35 years mostly as a result of anthropogenic afforestation in regions/countries such as Europe and China. If we consider that an hectare of commercial conifer plantation produces approximately between 4.0 to $4.5 \mathrm{~m}^{3}$ of sawn timber per year (Ramage et al., 2017b; Forestry-Commission, 2018) (i.e. $\approx 46 \mathrm{t}$ in 30 years) the land required to meet an additional $33 \mathrm{Mt}$ of timber (CLT) demand by 2050 (see Figure 4b) would be about $7200 \mathrm{~km}^{2}$. This corresponds to an increase in commercial forests of approximately $240 \mathrm{~km}^{2} / \mathrm{yr}$ for the next 30 years, a figure which is two orders of magnitude smaller than current afforestation trends $\left(+64000 \mathrm{~km}^{2} / \mathrm{yr}\right.$ for the past 35 years, based on Song et al. study).

\section{Discussion}

Results in Figure 6 show that cumulated GHG savings can range from about $10 \%$ of national annual emissions of countries like Spain to $10 \%$ of countries with much higher emissions like Germany, and on average represent $15 \%$ of national annual emissions of countries such as France, Italy, or the UK (Global Carbon Project, 2018). The average of $50 \mathrm{Mt} \mathrm{CO}_{2} \mathrm{e}$ also represents about five years worth of total UK cementitious material emissions (Shanks et al., 2019), or in different terms, it equates to take $\sim 11$ million cars off the road for an entire year (Environmental Protection Agency, 2018).

With respect to the remaining carbon budget, there exist different estimates about what is left for a $66 \%$ chance of less than $1.5{ }^{\circ} \mathrm{C}$ warming. These range from $118 \mathrm{Gt}$ $\mathrm{CO}_{2} \mathrm{e}$ (IPCC (2013) AR5 through an Earth System Model) to 300-700 $\mathrm{Gt} \mathrm{CO}_{2} \mathrm{e}$ (various estimates using observational data on emissions and warming Carbon Brief (2018)).

While our results indicate that savings are moderate in comparison to the budget $(<1 \%)$, the construction sector is notably one that is hard-to-decarbonise and which is a laggard in reducing GHG emissions. In this light, if we accept that construction is responsible for $\backsim 10 \%$ of all global emissions annually, the savings that hybrid systems can achieve would contribute some $1.5 \%$ reduction of that $10 \%$ (based on numbers from the Global Carbon Project (2018)). If carbon sequestration were accounted for, which we have not included in our analysis as a conservative approach, this contribution could 
be much greater. Notwithstanding, it is a non-trivial reduction, particularly given the immediate applicability of this material substitution strategy which does not require new technologies to be developed nor does it require upskilling of the current workforce in design, engineering, and construction practice.

\section{Conclusion}

Achieving substantial reductions of the current anthropogenic GHG emissions in the shortest possible amount of time has been unanimously waived as the only feasible way to avoid an imminent climate catastrophe. Projected forecasts of global urban growth combined with an increase in material consumption will certainly lead to a continuation of the current emissions trend unless alternative solutions are put in place. The building sector is, historically, among the greatest contributors to global GHG emissions. This remains true in spite of the continuous improvements in operational energy efficiency achieved in the last decades. As buildings become more efficient in their operational life, the material manufacturing and construction phases (and related upstream supply chains) are increasingly becoming the main carbon hotspot to focus on. This is due to the vast amounts of energy required to extract and process raw materials, manufacturing them into usable products and shipping them around during the various processing stages up to construction site, as well as due to the energy required for endof-life disposal. Steel and concrete are by far the two human-made materials in highest demand globally. Notably, they are also among the most energy and carbon-intensive ones. Even considering the optimistic assumption that very aggressive coordinated policies will eventually enable the global energy mix to become carbon-free by 2050 , steel and concrete are hard-to-de-carbonise materials, emitting $\mathrm{CO}_{2}$ as a direct result of the chemical reactions involved in their respective production processes. A way to mitigate global demand while providing the same service is to find valid low-carbon substitutes for specific construction applications.

In this paper we have attempted to quantify the potential global savings, in terms of avoided $\mathrm{CO}_{2}$ e emissions for the next 30 years, resulting from substituting concrete 
floor slabs in steel building frames with Cross Laminated Timber panels. Such substitution yields on average $50 \mathrm{Mt} \mathrm{CO}_{2}$ e of avoided emissions, without considering any carbon sequestration and storage potential offered by timber as a building material. At a time where climate change has rightly turned into climate crisis and emergency, urgency in implementing effective actions is of essence and the hybrid system presented in this research represents an immediately viable route to decarbonise buildings and construction.

Future work could address some of the limitations of the research presented in this paper, such as a regionalised approach to estimate GHG emissions linked to the main materials used in structural systems, or to expand the analysis beyond the structural frame only and explore material substitution potential in other building elements and assemblies.

\section{Acknowledgements}

The work presented herein was partially funded by the UK Engineering and Physical Sciences Research Council (EPSRC), grant agreement: EP/R01468X/1.

\section{References}

Abergel, T., Dean, B., Dulac, J., 2017. Towards a zero-emission, efficient, and resilient buildings and construction sector: Global status report 2017. UN Environment and International Energy Agency: Paris, France. URL: http://hdl . handle. net/20 . $500.11822 / 27140$. [Accessed: 13-06-2020].

International Energy Agency, 2000. Greenhouse gas emissions from major industrial sources-iii: Iron and steel production. URL: https://ieaghg.org/ docs/General_Docs/Reports/PH3-30\%20iron-steel.pdf. [Accessed: 1306-2020].

International Energy Agency, 2009a. Cement technology roadmap - carbon emissions reductions up to 2050. doi:https://doi.org/10.1787/9789264088061-en. 
International Energy Agency, 2009b. Energy technology transitions for industry strategies for the next industrial revolution. doi:https://doi.org/10.1787/ $9789264068612-$ en.

International Energy Agency, 2017. Tracking clean energy progress. www.iea.org/ etp/tracking2017/. [Accessed: 11-12-2019].

International Energy Agency, 2018. World Energy Outlook. https://www.iea. org/weo2018/. [Accessed: 06-09-2019].

International Energy Agency, 2019. Tracking buildings. https://www.iea.org/ reports/tracking-buildings. [Accessed: 11-12-2019].

Environmental Protection Agency, U.S., 2018. Greenhouse gas emissions from a typical passenger vehicle URL: https://www.epa.gov/greenvehicles/ greenhouse-gas-emissions-typical-passenger-vehicle. [Accessed: 2102-2020].

Allen, M.R., Frame, D.J., Huntingford, C., Jones, C.D., Lowe, J.A., Meinshausen, M., Meinshausen, N., 2009. Warming caused by cumulative carbon emissions towards the trillionth tonne. Nature 458, 1163. doi:https://doi.org/10.1038/ nature08019.

Allwood, J.M., 2018. Unrealistic techno-optimism is holding back progress on resource efficiency. Nature materials 17, 1050. doi:https://doi.org/10.1038/ s41563-018-0229-8.

Allwood, J.M., Ashby, M.F., Gutowski, T.G., Worrell, E., 2011. Material efficiency: A white paper. Resources, Conservation and Recycling 55, 362-381. doi:https: //doi.org/10.1016/j.resconrec.2010.11.002.

Allwood, J.M., Cullen, J.M., Carruth, M.A., Cooper, D.R., McBrien, M., Milford, R.L., Moynihan, M.C., Patel, A.C., 2012. Sustainable materials: with both eyes open. UIT Cambridge Cambridge. 
Waugh Thistleton Architects, 2018. 6 Orsman road - timber office on the Regents canal. http://waughthistleton.com/6-orsman-road/. [Accessed: 12-01-2020].

Carbon Brief, 2018. Analysis: how much 'carbon budget' is left to limit global warming to 1.5c? https://www.carbonbrief.org/ analysis-how-much-carbon-budget-is-left-to-limit-global-warming-to-1-5c. [Accessed: 19-02-2020].

Brütting, J., Desruelle, J., Senatore, G., Fivet, C., 2019. Design of truss structures through reuse. Structures 18, 128-137. doi:https://doi.org/10.1016/ j.istruc.2018.11.006.

Bukauskas, A., Shepherd, P., Walker, P., Sharma, B., Bregulla, J., 2018. Inventoryconstrained structural design: New objectives and optimization techniques, in: Proceedings of IASS Annual Symposium, International Association for Shell and Spatial Structures (IASS).

Committee on Climate Change, 2018a. Biomass in a low-carbon economy. https://www.theccc.org.uk/wp-content/uploads/2018/11/ Biomass-in-a-low-carbon-economy-CCC-2018.pdf. [Accessed: 15-012020].

Committee on Climate Change, 2018b. Reducing UK Emissions - Progress Report to Parliament. https://www.theccc.org.uk/publication/ reducing-uk-emissions-2018-progress-report-to-parliament/. [Accessed: 23-12-2019].

Chen, C.X., Pierobon, F., Ganguly, I., 2019. Life cycle assessment (LCA) of crosslaminated timber (clt) produced in western washington: The role of logistics and wood species mix. Sustainability 11, 1278. doi:https://doi.org/10.3390/ su11051278.

Chiniforush, A.A., Akbarnezhad, A., Valipour, H., Xiao, J., 2018. Energy implications 
of using steel-timber composite (STC) elements in buildings. Energy and Buildings 176, 203-215. doi:https://doi.org/10.1016/j.enbuild.2018.07.038.

Churkina, G., Organschi, A., Reyer, C.P.O., Ruff, A., Vinke, K., 2020. Building a global carbon sink. Nature Sustainability doi:https://doi.org/10.1038/ s41893-019-0462-4.

World Green Building Council, 2019. Bringing Embodied Carbon Upfront. https: //www.worldgbc .org/embodied-carbon. [Accessed: 11-02-2020].

Crawford, R.H., Cadorel, X., 2017. A framework for assessing the environmental benefits of mass timber construction. Procedia engineering 196, 838-846. doi:https : / / doi . org/10.1016/j.proeng.2017.08.015.

Cullen, J.M., Allwood, J.M., Bambach, M.D., 2012. Mapping the global flow of steel: from steelmaking to end-use goods. Environmental science \& technology 46, 1304813055. doi:https://doi.org/10.1021/es302433p.

D'Amico, B., Pomponi, F., 2018. Accuracy and reliability: a computational tool to minimise steel mass and carbon emissions at early-stage structural design. Energy and Buildings 168, 236-250. doi:https://doi.org/10.1016/j.enbuild. 2018.03 .031$.

D'Amico, B., Pomponi, F., 2019. A compactness measure of sustainable building forms. Royal Society open science 6, 181265. doi:https://doi.org/10.1098/rsos. 181265.

Davis, S.J., Lewis, N.S., Shaner, M., Aggarwal, S., Arent, D., Azevedo, I.L., Benson, S.M., Bradley, T., Brouwer, J., Chiang, Y.M., et al., 2018. Net-zero emissions energy systems. Science 360, eaas9793. doi:https://doi.org/10.1126/science. aas 9793.

Dean, C.C., Dugwell, D., Fennell, P.S., 2011. Investigation into potential synergy be- 
tween power generation, cement manufacture and $\mathrm{CO} 2$ abatement using the calcium looping cycle. Energy \& Environmental Science 4, 2050-2053.

Espinoza, O., Trujillo, V.R., Mallo, M.F.L., Buehlmann, U., 2016. Cross-laminated timber: Status and research needs in europe. BioResources 11, 281-295. doi:https: //doi.org/10.15376/biores.11.1.281-295.

Forestry-Commission, 2018. Forest Research Forestry Statistics. https: //www.forestresearch.gov.uk/tools-and-resources/statistics/ forestry-statistics/forestry-statistics-2018/. [Accessed: 16-082019].

Foster, R.M., Reynolds, T.P., 2018. Lightweighting with timber: An opportunity for more sustainable urban densification. Journal of Architectural Engineering 24, 02518001. doi:https: //doi .org/10.1061/(ASCE) AE.1943-5568.0000301.

Güneralp, B., Zhou, Y., Ürge-Vorsatz, D., Gupta, M., Yu, S., Patel, P.L., Fragkias, M., Li, X., Seto, K.C., 2017. Global scenarios of urban density and its impacts on building energy use through 2050. Proceedings of the National Academy of Sciences 114, 8945-8950. doi:https://doi.org/10.1073/pnas.1606035114.

Gustavsson, L., Pingoud, K., Sathre, R., 2006. Carbon dioxide balance of wood substitution: comparing concrete-and wood-framed buildings. Mitigation and adaptation strategies for global change 11, 667-691. doi:https://doi.org/10.1007/ s11027-006-7207-1.

Hart, J., Pomponi, F., 2020. More timber in construction: Unanswered questions and future challenges. Sustainability 12, 3473. doi:https://doi.org/10.3390/ su12083473.

Harte, A.M., 2017. Mass timber - the emergence of a modern construction material. Journal of Structural Integrity and Maintenance 2, 121-132. doi:https://doi . org/10.1080/24705314.2017.1354156. 
Hassan, O.A., Öberg, F., Gezelius, E., 2019. Cross-laminated timber flooring and concrete slab flooring: A comparative study of structural design, economic and environmental consequences. Journal of Building Engineering, 100881doi:https: //doi.org/10.1016/j.jobe.2019.100881.

Hassanieh, A., Valipour, H., Bradford, M., 2016. Experimental and numerical study of steel-timber composite (STC) beams. Journal of Constructional Steel Research 122, 367-378. doi:https://doi.org/10.1016/j.jcsr.2016.04.005.

Haszeldine, R.S., 2009. Carbon capture and storage: how green can black be? Science 325, 1647-1652. doi:https://doi.org/10.1126/science.1172246.

Hawkins, W., Orr, J.J., Shepherd, P., Ibell, T.J., Bregulia, J., 2017. Thin-shell textilereinforced concrete floors for sustainable buildings, in: Proceedings of IASS Annual Symposium, International Association for Shell and Spatial Structures (IASS).

IPCC, 2013. Intergovernmental Panel on Climate Change. Working Group I Contribution to the Fifth Assessment Report of the Intergovernmental Panel on Climate Change. Climate Change 2013 - The Physical Science Basis [Stocker, T.F., D. Qin, G.-K. Plattner, M. Tignor, S.K. Allen, J. Boschung, A. Nauels, Y. Xia, V. Bex and P.M. Midgley (eds.)]. Cambridge University Press. URL: https://www.ipcc.ch/site/assets/uploads/2018/03/ WG1AR5_SummaryVolume_FINAL.pdf. [Accessed: 14-06-2020].

IPCC, 2018. Intergovernmental Panel on Climate Change, Global Warming of $1.5^{\circ} \mathrm{C}$. https: //www.ipcc.ch/sr15/. [Accessed: 05-09-2019].

Jaiswal, K., Wald, D.J., 2008. Creating a global building inventory for earthquake loss assessment and risk management. Technical Report. Geological Survey (US). URL: https://pubs.usgs.gov/of/2008/1160/downloads/ OF 08-1160.pdf. [Accessed: 13-06-2020].

Kuzmanovska, I., Gasparri, E., Tapias, D., Monne, M.A., 2018. Tall timber buildings: emerging trends and typologies, in: WCTE2018, World Confer- 
ence on Timber Engineering. URL: https://adk.elsevierpure.com/ ws/portalfiles/portal/63324909/WCTE_2018_Paper_TALI_TIMBER_ BUILDINGS_EMERGING_TRENDS_AND_TYPOLOGIES.pdf.

Lee, A.D., Shepherd, P., Evernden, M.C., Metcalfe, D., 2018. Optimizing the architectural layouts and technical specifications of curtain walls to minimize use of aluminium. Structures 13, 8-25. doi:https://doi.org/10.1016/j.istruc. 2017.10 .004 .

Liew, A., López, D.L., Van Mele, T., Block, P., 2017. Design, fabrication and testing of a prototype, thin-vaulted, unreinforced concrete floor. Engineering Structures 137, 323-335. doi:https://doi.org/10.1016/j.engstruct.2017.01.075.

Liu, Y., Guo, H., Sun, C., Chang, W.S., 2016. Assessing cross laminated timber (CLT) as an alternative material for mid-rise residential buildings in cold regions in china- $\mathrm{a}$ life-cycle assessment approach. Sustainability 8, 1047. doi:https://doi •org/10 . $3390 /$ su 8101047 .

Loss, C., Piazza, M., Zandonini, R., 2016. Connections for steel-timber hybrid prefabricated buildings. Part I: Experimental tests. Construction and Building Materials 122, 781-795. doi:https://doi.org/10.1016/j.conbuildmat.2015.12.002.

Loss, C., Rossi, S., Tannert, T., 2018. In-plane stiffness of hybrid steel-crosslaminated timber floor diaphragms. Journal of Structural Engineering 144, 04018128. doi:https://doi.org/10.1061/(ASCE) ST.1943-541X.0002105.

Lu, H.R., El Hanandeh, A., Gilbert, B.P., 2017. A comparative life cycle study of alternative materials for australian multi-storey apartment building frame constructions: Environmental and economic perspective. Journal of Cleaner Production 166, 458-473. doi:https://doi.org/10.1016/j.jclepro.2017.08.065.

Moynihan, M.C., Allwood, J.M., 2014. Utilization of structural steel in buildings. Proc. R. Soc. A 470, 20140170. doi:https://doi.org/10.1098/rspa.2014.0170. 
World Meteorological Organization, United Nations Environment Programme, 2019.

United In Science - High-level synthesis report of latest climate science information convened by the Science Advisory Group of the UN Climate Action Summit. https: //wedocs. unep.org/handle/20.500.11822/30023. [Accessed: 10-02-2020].

Pierobon, F., Huang, M., Simonen, K., Ganguly, I., 2019. Environmental benefits of using hybrid CLT structure in midrise non-residential construction: An LCA based comparative case study in the US pacific northwest. Journal of Building Engineering 26, 100862. doi:https://doi.org/10.1016/j.jobe.2019.100862.

Pomponi, F., D'Amico, B., Moncaster, A.M., 2017. A method to facilitate uncertainty analysis in LCAs of buildings. Energies 10, 524. doi:https: / / doi . org/10.3390/ en10040524.

Global Carbon Project, 2018. Global Carbon Atlas URL: http://www . globalcarbonatlas.org/en/CO2-emissions. [Accessed: 15-02-2020].

PWC-Metals, 2015. Steel in 2025: quo vadis? https://Www.pwc.com/gx/en/ metals/pdf/metals-stahlmarkt-2015.pdf. [Accessed: 13-01-2020].

Ramage, M., Foster, R., Smith, S., Flanagan, K., Bakker, R., 2017a. Super tall timber: design research for the next generation of natural structure. The Journal of Architecture 22, 104-122. doi:https://doi .org/10.1080/13602365.2016.1276094.

Ramage, M.H., Burridge, H., Busse-Wicher, M., Fereday, G., Reynolds, T., Shah, D.U., Wu, G., Yu, L., Fleming, P., Densley-Tingley, D., et al., 2017b. The wood from the trees: The use of timber in construction. Renewable and Sustainable Energy Reviews 68,333-359. doi:https://doi.org/10.1016/j.rser.2016.09.107.

Arup Foresight Research, Innovation, 2019. Rethinking timber buildings. https://www.arup.com/perspectives/publications/research/ section/rethinking-timber-buildings. [Accessed: 16-01-2020]. 
Robertson, A.B., Lam, F.C., Cole, R.J., 2012. A comparative cradle-to-gate Life Cycle Assessment of mid-rise office building construction alternatives: laminated timber or reinforced concrete. Buildings 2, 245-270. doi:https://doi.org/10.3390/ buildings2030245.

Ross, K., 2019. Cross-Laminated Timber: The sustainable choice of Microsoft Silicon valley. https://www.linkedin.com/pulse/ cross-laminated-timber-sustainable-choice-microsoft-silicon-ross/. [Accessed: 10-01-2020].

Salazar, J., Meil, J., 2009. Prospects for carbon-neutral housing: the influence of greater wood use on the carbon footprint of a single-family residence. Journal of Cleaner Production 17, 1563-1571. doi:https://doi.org/10.1016/j.jclepro.2009. 06.006 .

Sandanayake, M., Lokuge, W., Zhang, G., Setunge, S., Thushar, Q., 2018. Greenhouse gas emissions during timber and concrete building construction-a scenario based comparative case study. Sustainable Cities and Society 38, 91-97.

Shanks, W., Dunant, C., Drewniok, M.P., Lupton, R., Serrenho, A., Allwood, J.M., 2019. How much cement can we do without? lessons from cement material flows in the uk. Resources, Conservation and Recycling 141, 441-454. doi:https://doi. org/10.1016/j.resconrec.2018.11.002.

SOM, 2013. Timber tower research project. https://www.som.com/ideas/ research/timber_tower_research_project. [Accessed: 12-01-2020].

Song, X.P., Hansen, M.C., Stehman, S.V., Potapov, P.V., Tyukavina, A., Vermote, E.F., Townshend, J.R., 2018. Global land change from 1982 to 2016. Nature 560, 639. doi:https://doi.org/10.1038/s41586-018-0411-9.

European Committee for Standardization, 2011. EN 15978, Sustainability of construction works-assessment of environmental performance of buildings- 
calculation method. URL: https://shop.bsigroup.com/ProductDetail? pid=000000000030256638.

SteelConstruction.info, 2018. Composite construction. https://www . steelconstruction.info/Composite_construction. [Accessed: 1601-2020].

Holmes Structures, 2017. Brentwood public library - Brentwood, California. https://www.holmesstructures.com/portfolio-articles/ brentwood-public-library/. [Accessed: 12-01-2020].

Tesfamariam, S., Stiemer, S., Dickof, C., Bezabeh, M., 2014. Seismic vulnerability assessment of hybrid steel-timber structure: Steel moment-resisting frames with CLT infill. Journal of Earthquake Engineering 18, 929-944. doi:https : / doi . org/10 . $1080 / 13632469.2014 .916240$.

Tettey, U.Y.A., Dodoo, A., Gustavsson, L., 2019. Effect of different frame materials on the primary energy use of a multi storey residential building in a life cycle perspective. Energy and Buildings 185, 259-271. doi:https://doi.org/10.1016/ j.enbuild.2018.12.017.

UN, 2018. 2018 revision of world urbanization prospects. URL: https://tinyurl . com/yd5 lp46y. [Accessed: 13-06-2020].

Xia, B., O’Neill, T., Zuo, J., Skitmore, M., Chen, Q., 2014. Perceived obstacles to multistorey timber-frame construction: an australian study. Architectural science review 57, 169-176. doi:https://doi.org/10.1080/00038628.2014.912198.

Yue, M., Li, W., Cheng, X., Chen, Y., Xu, L., Shi, Y., 2019. Study on energy conservation and carbon emission reduction design of timber structure building. The Journal of Engineering 2019, 5455-5466. doi:10.1049/joe.2018.5251. 